\title{
余震や繰り返し加力に対する劣化を抑制した壁を組み込んだ 木造住宅の振動台実験

\author{
SHAKING TABLE TEST OF WOOD HOUSE WITH NO DEGRADATION SHEAR WALL TO \\ SUSTAIN SEISMIC PERFORMANCE AGAINST AFTERSHOCK AND CYCLIC LOADING
}

\author{
峯村廣 紀*, 五十田 博**, 服部 学*** \\ Hiroki MINEMURA, Hiroshi ISODA and Manabu HATTORI
}

\begin{abstract}
One of key issues of recent seismic structural design for buildings is the safety performance against long duration earthquake, repeated earthquake and severe earthquake after main shock. It may be difficult for conventional shear walls of wood house such as bracing and plywood shear wall to survive during their earthquake.

In this study, shear wall with high stiffness rubber was proposed to prevent the degradation of seismic performance during repeated earthquakes and shear wall test and shaking table test were conducted in comparison with plywood conventional shear wall. Following results were obtained:

1 In shear wall test, it was found that no degradation occurred in proposed shear wall in the range of 1/30rad.

2 In shaking table test, the specimen without proposed shear wall was damaged in three times severe earthquakes, while the specimen with it was survived in five times severe earthquakes.
\end{abstract}

Keywords : Static loading test, Shaking table test, High-hardness rubber, cyclic load, Strength degradation, Energy absorption 静的載荷実験, 振動台実験, 高硬度ゴム, 繰り返し荷重, 而力劣化, エネルギー吸収

\section{1. はじめに}

2004 年新潟県中越地震では震度 6 強程度の地震動が繰り返し発 生し、余震による建物の被害もみられた。2011 年東北地方太平洋沖 地震は 2 つの主要動があり、継続時間は 2 分以上と長く、その後、 震度 6 強の余震も頻発している。また、長期優良住宅では、これま で 30 年程度と考えられていた供用期間をはるかに超え、100 年、 200 年といった期間を想定した住宅を建てていくことを推進してい る。これらに共通した耐震上の問題点は、繰り返し作用寸る地震動 に対する安全性の確保である。

ここで、現状の木造住宅の耐震性にかかわる壁の評価を木造軸組 工法住宅の許容応力度設計 ${ }^{1)}$ の実験評価を参考にみると、1/480 $\mathrm{rad}$ から $1 / 50 \mathrm{rad}$ まで 3 回の定振幅正負載荷を繰り返した後、得られた 骨格曲線に基づいて評価する、としている。つまり 1/50rad までの 範囲で 3 回程度の繰り返しが考慮され、大地震時の性能を評価して いる、と解釈できる。しかし、1/30 rad に至るような極大地震の繰 り返しは考慮されてはいない。一方で長期優良住宅の耐震に関する 評価基準では、必要壁量や短期許容せん断耐力を 1.25 倍や 1.5 倍に 割り増して、あるいは限界耐力計算では限界変形を $1 / 30 \mathrm{rad}$ から 1/40 rad に抑えて設計をする。ここでは耐力を向上させることによ
り、あるいは変形を抑えることにより繰り返しに対しての性能を担 保している。また、再現期間が長くなることにより想定する地震動 が大きくなるため、それを耐力の割り増しや変形の抑制により代替 している、という考え方もあるようである。とにかく、余震や繰り 返し発生する地震に対する性能の確保は今後考慮を必要とする重要 な課題であるが、現在の評価法で確保されているか、あいまいな点 は多い。

ここで、このような繰り返し地震に対する耐震性能に関しての既 往の研究をみると、個別物件に対して性能を確認したもの 2)、壁の 繰り返し実験に基づき定振幅での強度劣化を確認したもの3)、など がある。壁の繰り返し実験では一般の壁は繰り返し性能の確保が難 しいことが述べられている。筆者らも復元力特性の構築とその確認 を目的に定振幅繰り返し実験 4)や繰り返し地震動が入力された振動 台実験 5)を通じ、繰り返しに対する地震時の建物性能を確認してき た。これらの論文は目的が異なるため、繰り返しの性能について十 分な考察ができていないが、骨格曲線を繰り返し変形に対して劣化 するように定義するなど、一般の耐力壁が繰り返しに対し劣化する ことを暗に示している。なお、繰り返し作用する外力、という意味 では、風荷重のほうが繰り返し数は多いと考えられる。下村らによ

Graduate Student, Graduate School of Engineering, Shinshu Univ. Prof., Research Institute for Sustainable Humanosphere, Kyoto Univ., Dr. Eng.

Sumitomo Rubber Industries, Ltd.
* 信州大学大学院 修士課程

** 京都大学生存圈研究所生活圈構造機能分野 教授・博士 (工学)

*** 住友ゴム工業(株) 
り実験等に基づきそのモデル化がなされた事例 6)がある。

本論文では、構造用合板を用いた高耐力な住宅の繰り返し地震動 に対する性能の劣化の一例を示すとともに、これまで筆者らが開発 に関与してきた制振用高硬度ゴムを用いた壁（以下、制振壁と称す る）について、繰り返し作用する地震動に対する有効性を示したも のである。有効性を示す方法として、3P $\times 3 \mathrm{P} （ 1 \mathrm{P}=910 \mathrm{~mm} ）$ の平 屋箱型模型振動台実験を実施し、応答低減効果、エネルギー吸収効 果、ならびに繰り返し加振による性能劣化を構造用合板壁の場合と 比較した。また、高硬度ゴムの繰り返し実験とともに制振壁の繰り 返し実験を実施し、一般の繰り返し実験による構造用合板壁と比較 した。

\section{2. 本論で対象とする高硬度ゴムの性質}

図 1 に高硬度ゴムの繰り返し実験のせん断応力度-歪関係、繰り返 しによる性能劣化、温度依存性、振動数依存性と等価せん断弾性係 数 Geq の変化率の関係を示す。繰り返しの実験では $20 \%$ のん断 歪み、温度、振動依存性の実験は $100 \%$ のん断歪に対して実施し ている。せん断応力度一歪夕関係をみると、初期に高剛性の後降伏し、 2 次勾配を有し、さらに終局的にはハードニングを生じている。繰 り返し依存性では、50 回程度までの繰り返し回数では、低下傾向が みられるが、その後はサイクルを増加させても安定した值となって おり、繰り返しによる劣化が少ないことがわかる。温度依存性や速 度依存性は使用環境の範囲で 0.5 2 倍程度まで変化するが、一般の 制振用ゴム材料と比較すると、依存性の少ない材料といえる。

\section{3. 提案壁の強度特性}

\section{1 抵抗機構と各部詳細}

図 2 に制振壁の抵抗機構と各部詳細を示す。変形時の抵抗機構は 図 2 上に示寸ようないわゆるシアリンク型 7) や間柱型 8) と呼ばれ るもので、梁下に設置した構造用合板に取り付けられた鋼製部材と 土台に設置された三角形状に組まれた角型鋼管部分に高硬度ゴムを 取り付けた形状である。高硬度ゴムは、上下で鋼製部材に支持され、 その支持部材は梁部ではラグスクリュー、基礎部・土台部ではアンカ 一ボルトでそれぞれ緊結している。高硬度ゴムの水平方向の可動範 囲は土60mm である。後述する通り、壁の大変形時には、水平変位 を 1.0 としてダンパーの変形割合が 0.5 に達寸る。つまり、壁高さ $2,730 \mathrm{~mm}$ の場合では、水平変位にして $60 / 0.5=120 \mathrm{~mm}$ 、変形角に しておよそ1/23rad までストッパーにはあたらずに可動する。また、 梁下の構造用合板は壁高さの変化に対応できるように設置したもの で、梁にボルトとラグスクリューを用いて留め付けている。なお、 壁高さがある程度高くなる時には構造用合板を LVLに置き換える。 置き換えによっても性能に変化がないことを別途実験により確認し ている。また、面内座屈防止のため鋼製横栈を角型鋼管に M8 ボル 卜で留め付けるとともに、軸組に木製横栈を配置した。脚部では鋼 製部材の土台へのめり込みを、鋼管スリーブを土台内に挿入するこ とで防止している。制振壁で用いる軸組の部材断面はそれぞれ、桁 $180 \times 105 \mathrm{~mm}$ 、柱 $105 \times 105 \mathrm{~mm}$ 、土台 $105 \times 105 \mathrm{~mm}$ である。

\section{2 実験方法と実験結果}

試験方法は柱の両端に HD ボルトを設置した柱脚固定式で実施し た。加力はアクチュエーターによる変位制御の正負交番 3 回繰り返
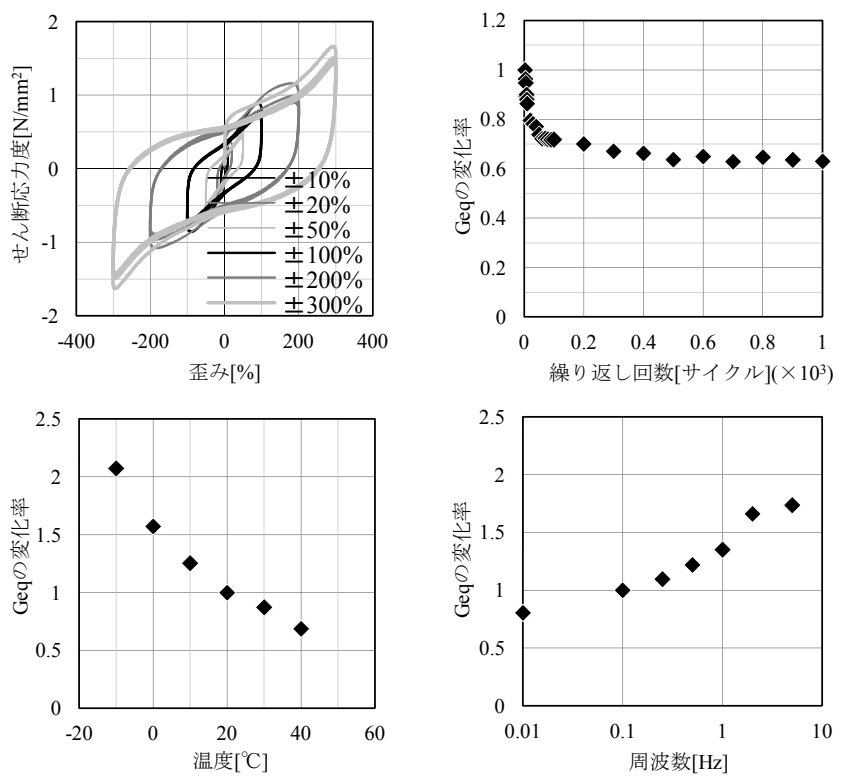

図 1 本高硬度ゴムの性質
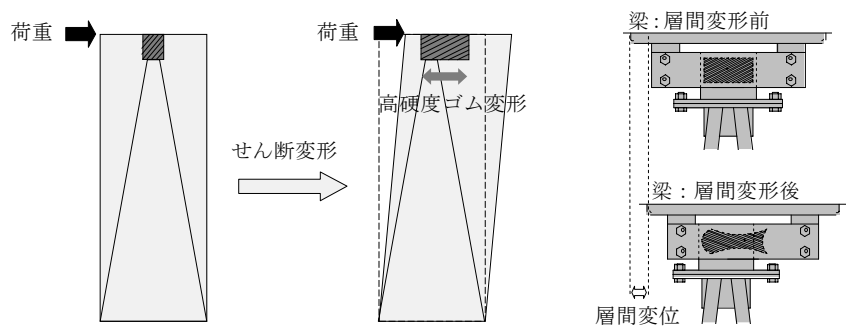

変形機構 : 壁のせん断変形を利用し、層間変形を直接高硬度ゴムに伝達する
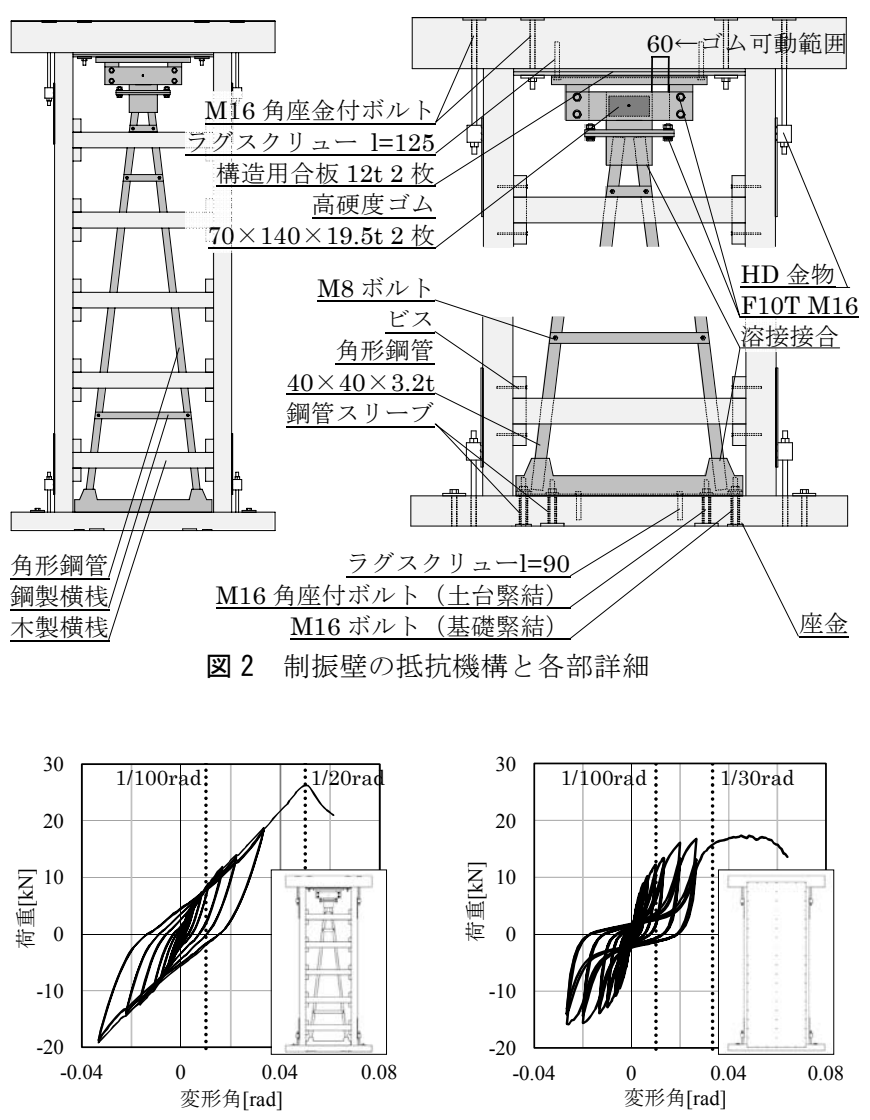

図 3 荷重-変形関係（左：制振壁、右：構造用合板壁） 
し載荷とし、目標変形角を柱脚部の浮き上がりに起因する变形角を 含む見かけのせん断変形角で制御し、1/480、1/360、1/240、1/180、 $1 / 120 、 1 / 90 、 1 / 60 、 1 / 45 、 1 / 30 \mathrm{rad}$ と、一般の性能評価の試験より も大きな変形角 $1 / 30 \mathrm{rad}$ まで繰り返す方法とした。その後、荷重が 最大荷重の $80 \%$ に低下寸るか、見かけのせん断変形角が $1 / 15 \mathrm{rad}$ 以 上に達するまでを目標に実施した。

図 3 に壁実験から得られた制振壁の荷重変形関係を示す。ここに は、一般的な耐力壁との比較のため、構造用合板壁のそれも併せて 示した。構造用合板壁の仕様は、芯々で、幅 $910 \mathrm{~mm}$ 、試験体高さ $2,730 \mathrm{~mm}$ の軸組に、 $t=9 \mathrm{~mm}$ の構造用合板を釘ピッチ $150 \mathrm{~mm}$ 間隔 で、両面張りしたものである。用いている軸組の部材断面は本制振 壁と同様で、桁 $180 \times 105 \mathrm{~mm}$ 、柱 $105 \times 105 \mathrm{~mm}$ 、土台 $105 \times 105 \mathrm{~mm}$ である。また、繰り返し加力は一般の耐力壁評価とほぼ同じである。 制振壁は層間変形角約 $1 / 20 \mathrm{rad}$ で、最大荷重 $26.3 \mathrm{kN}$ に達し、角型 鋼管の面内座屈の後、荷重が低下した。初期の繰り返し時に若干の すべり挙動がみられるが、大変形時には繰り返し時であっても安定 したループ形状がみてとれる。終局的な剛性は高く、破壊まで荷重 が上昇している。図 4 は層間変形を 1.0 とした場合のダンパーの変 形割合を各変形角において示したものである。変形が小さい範囲で はダンパーの変形量は少ない。つまり、スリップは周辺部材のすべ りに起因していると考えられる。変形が大きくなるとそのすべりの 全体変形に占める量は少なく、ダンパーに 0.5 の変形が生じている。 このようにすべりが増加していないことからも周辺部材や接合部は 終局に近い荷重までほぼ弾性的な挙動と推定される。一方で構造用 合板をみると、1/100 rad 程度で降伏後、荷重の上昇はわずかである。 さらに繰り返し時にスリップとピンチング挙動がみられる。

表 1 はそれぞれの壁について、壁倍率の算出時に用いられる4つ の指標 1)を示したものである。制振壁は勒性が小さく Ds が大きく なったことと、剛性が低くその結果 1/120 rad 時の耐力が低いため、 壁倍率は 4.3 にとどまった。一方の構造用合板は設計で用いられる 2.5 倍を 2 倍した程度の 5.1 倍であった。開発した制振壁は壁倍率 評価では構造用合板 2 枚ばりの $84 \%$ 程度である。

図 5 には繰り返し時の耐力劣化を確認することを目的に、各目標 変形角、各サイクルにおける荷重の最大值を示した。なお、荷重は 押し引きの平均值である。全体的な傾向として、制振壁は繰り返し 時の耐力低下がなく、構造用合板は 1 サイクルから 2 サイクルでの 低下が大きいこと、が読み取れる。たとえば、それぞれの最大変形 角における荷重低下みると、制振壁は 1 サイクル目で $19.0 \mathrm{kN} 、 2$ サ イクル目で $18.6 \mathrm{kN} 、 3$ サイクル目で $18.5 \mathrm{kN}$ であり、1 サイクル目と 2 サイクル目の荷重の差は $0.4 \mathrm{kN} 、 2$ サイクル目と 3 サイクル目の荷 重の差は $0.1 \mathrm{kN}$ である。構造用合板の繰り返し載荷は、1/300 rad か らはじめ、 $\sqrt{2}$ 倍ずつ変形を繰り返しながら $1 / 37.5 \mathrm{rad}$ まで実施して おり、最大変形角の $1 / 37.5 \mathrm{rad}$ 時の荷重は、1 サイクル目で $16.3 \mathrm{kN}$ 、 2 サイクル目で $13.6 \mathrm{kN} 、 3$ サイクル目で $12.6 \mathrm{kN}$ であった。1 サイク ル目と 2 サイクル目の荷重の差は $2.7 \mathrm{kN} 、 2$ サイクル目と 3 サイクル 目の荷重の差は $1.0 \mathrm{kN}$ であった。壁倍率評価では構造用合板 2P の ほうが高いが、繰り返し時の耐力低下の絶対值は制振壁のほうが小 さい。また、図 5 は骨格曲線の比較ともみることができる。1/50 rad までは構造用合板のほうが大きく、それ以降は逆転し、制振壁のほ うが大きくなっている。

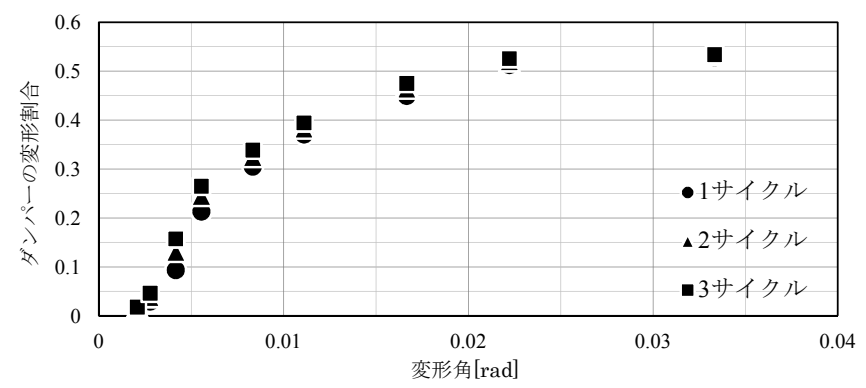

図 4 層間変形に占めるダンパーの変形割合

表 1 特性值

\begin{tabular}{c|c|c|c|c|c}
\hline 試験体 & $\mathrm{P}_{\mathrm{y}[\mathrm{kN}]}$ & $2 / 3 \mathrm{P}_{\max }[\mathrm{kN}]$ & $0.2 \mathrm{P}_{\mathrm{u}} / \mathrm{D}_{\mathrm{s}}[\mathrm{kN}]$ & $\mathrm{P}_{1 / 120[\mathrm{kN}]}$ & 壁倍率 \\
\hline 制振壁 & 11.4 & 17.5 & $7.7\left(\mathrm{Ds}^{2}=0.57\right)$ & 8.0 & 4.3 \\
\hline 合板壁 & 9.1 & 11.5 & $11.0(\mathrm{Ds}=0.28)$ & 11.0 & 5.1 \\
\hline
\end{tabular}
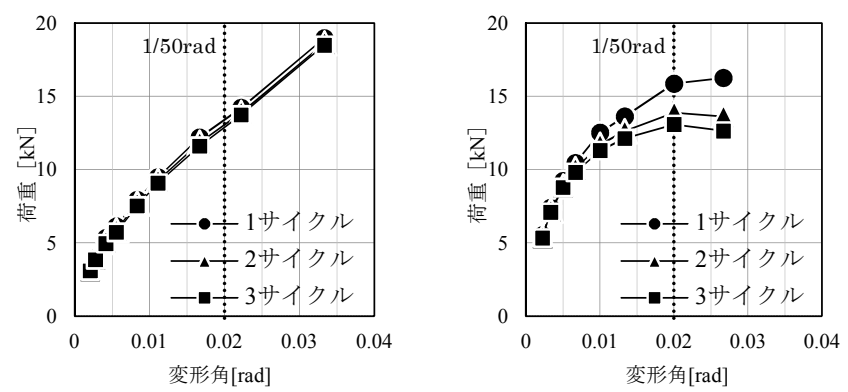

図 5 荷重の最大点（左：制振壁、右：構造用合板壁）
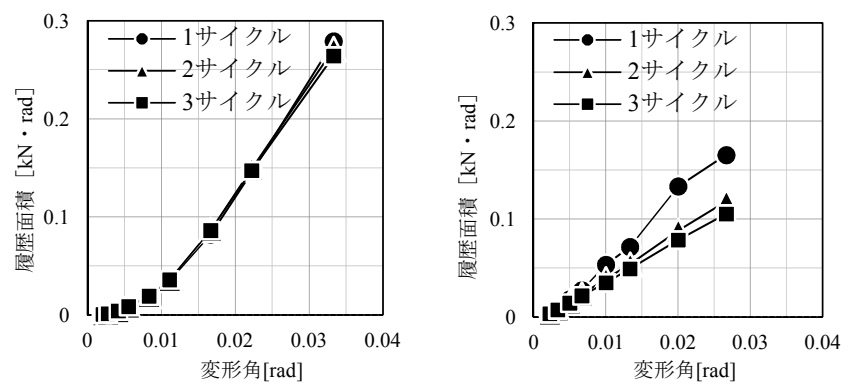

図 6 履歴ループの面積（左 : 制振壁、右 : 構造用合板壁 $)$

図 6 は同様の検討を履歴面積に対して実施したものである。なお、 面積は同一変形角における押し引きの半ループあたりの面積を算出 し、それを平均したものである。履歴面積で比較しても荷重と同様 に制振壁で繰り返しによる劣化がないこと、さらに履歴で囲まれる 面積の絶対量が大きいこと、がみてとれる。

\section{4．振動台実験による繰り返し加力の影響}

\section{1. 試験概要}

図 7 に試験体平面を示す。ここで試験パラメータ構面とは中央構 面を指し、各試験体で異なる。試験体は芯々で、平面形状 $2,730 \times$ $2,730 \mathrm{~mm}$ 、高さ $2,762.5 \mathrm{~mm}$ の平屋箱形である。各試験体の加振方 向外周部の耐力壁仕様は厚さ $9 \mathrm{~mm}$ の構造用合板で、 $\mathrm{N} 50$ 釷、ピッ チ $150 \mathrm{~mm}$ で打ち付けている。パラメータ構面は 2 種類あり、制振 壁としたものと制振壁と同じ壁倍率となるように設計した構造用合 


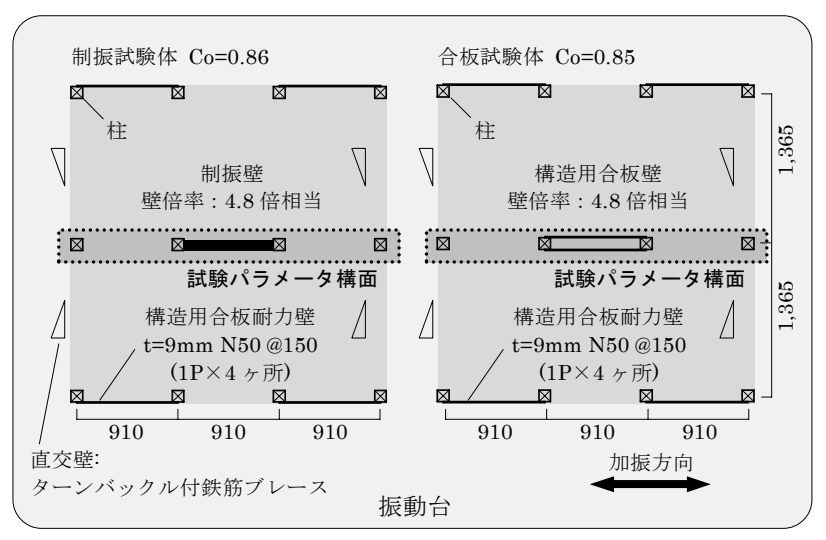

図 7 試験体概要

板壁である。つまり、構造用合板は両面ばりとして上下の横架材に 打ち付けられている釘を 1 本間引いたものである。参考文献 1)に示 される面材張大壁の詳細計算法によれば、壁倍率は 4.8 倍相当にな る。この 4.8 倍は振動台実験直前に実施した壁実験の結果 9)を参照 し、最も強くなる仕様から決定した。前述した 4.3 とこの 4.8 の違 いは、高さ調整をLVLに置き換えたことと、前述の壁実験が夏場に 実施されているのに対して、冬場に壁実験を実施したことに起因し ている。なお、本制振壁の温度依存性については文献 10)に示寸方法 と同様の方法で確認しているが、ここでは紙面の都合上省略寸る。 結局、耐力要素はそれぞれ、構造用合板 $4 \mathrm{P}+$ 制振壁 (以下、制振試 験体と称す)、構造用合板 $6 \mathrm{P}$ (以下、合板試験体と称す) で、制振 試験体では水平抵抗要素の約 $1 / 3$ を制振壁で占める。写真 1 に試験 体を振動台に設置した状況と試験体外側からパラメータ構面を写し たものを示した。加振は制振試験体と合板試験体の同時加振とした。 地震力算定用重量は、制振試験体で $30.8 \mathrm{kN}$ 、合板試験体で $31.2 \mathrm{kN}$ であり、このわずかな違いは壁自重の違いによる。層の短期許容耐 力を壁倍率 $\times$ 壁長さ $\times 1.96 \mathrm{kN}$ で求め、それを地震力算定用重量で 除した值である $\mathrm{C}_{0}$ は、合板試験体で $\mathrm{C}_{0}=0.85$ で、制振試験体では 壁倍率 4.3 倍では $0.83 、 4.8$ 倍では 0.86 である。制振壁で $\mathrm{C}_{0}$ を求 めると、壁倍率 4.3 では 0.25 、同 4.8 では 0.28 と、基準法を上回る 性能を有している。このように極めて大きな $\mathrm{C}_{0}$ 值としたのは、事前 の解析により本加振波として用いる JMA 神戸波に対して 1/45 rad 程度の応答に抑えることを目標にしたこと、さらにこの試験の前に 同時加振をした $4 \mathrm{P}$ 合板試験体が JMA 神戸波に対して倒壊に至らな い性能として定めた結果 $\left.{ }^{11}\right)$ である。なお、自重以外の重量は鋼製 の錘を 2 階床に載せて補った。

表 2 に加振スケジュールを示す。入力する加振波は建築基準法の 大地震を想定した BSL 波と前述したように 1995 年兵庫県南部地震 で観測された JMA 神戸波 NS 成分を用いた。BSL はランダム位相 で建築基準法に定める加速度応答スペクトルを想定した継続時間 20 秒の地震動である ${ }^{12)}$ 。また、中地震を想定した BSLの $20 \%$ の 力波ならびに余震を想定した BSLの $50 \%$ の力波も用いている。 また、各加振前後で、ランダム波、ステップ波を用いて振動特性を 求めた。BSL $100 \%$ と JMA 神戸波の Sa-Sd スペクトルをその目標 波と比較して図 8 に示す。BSL 波は振動台の制御の都合で長周期成 分がカットされ目標と異なったが、2.0 秒以上は影響のないものと 考えられる。神戸波は目標波が再現できている。

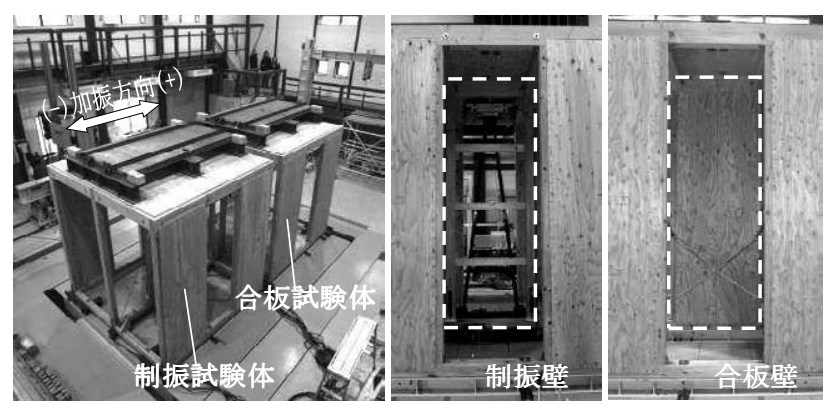

写真 1 試験体全景とパラメータ構面

表 2 加振スケジュール

\begin{tabular}{c|c|c|c}
\hline 加振波 No. & 加振波 & 縮小倍率 & 想定寸る地震規模 \\
\hline (1) & BSL 波 & $20 \%$ & 中地震 \\
\hline (2) & BSL 波 & $100 \%$ & 建築基準法大地震 \\
\hline (3) & JMA 神戸波-1 回目 & $100 \%$ & 極大地震 \\
\hline (4) & JMA 神戸波-2 回目 & $100 \%$ & 極大地震 \\
\hline (5) & JMA 神戸波-3 回目 & $100 \%$ & 極大地震 \\
\hline (6) & BSL 波 & $50 \%$ & 余震 \\
\hline (7) & JMA 神戸波-4 回目 & $100 \%$ & 極大地震 \\
\hline (8) & JMA 神戸波-5 回目 & $100 \%$ & 極大地震 \\
\hline
\end{tabular}
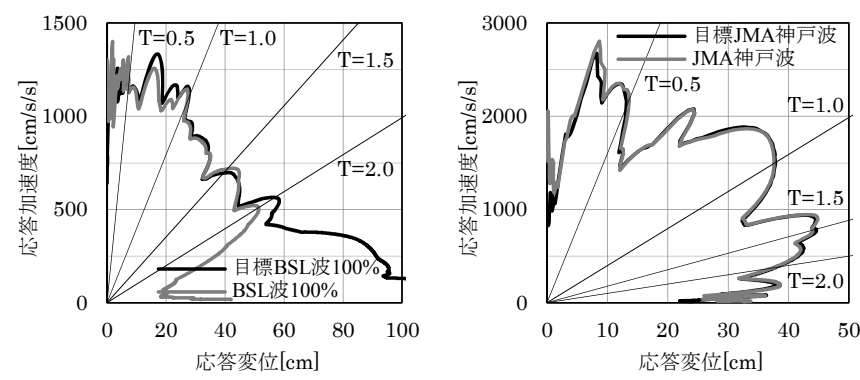

図 8 Sa-Sd スペクトル

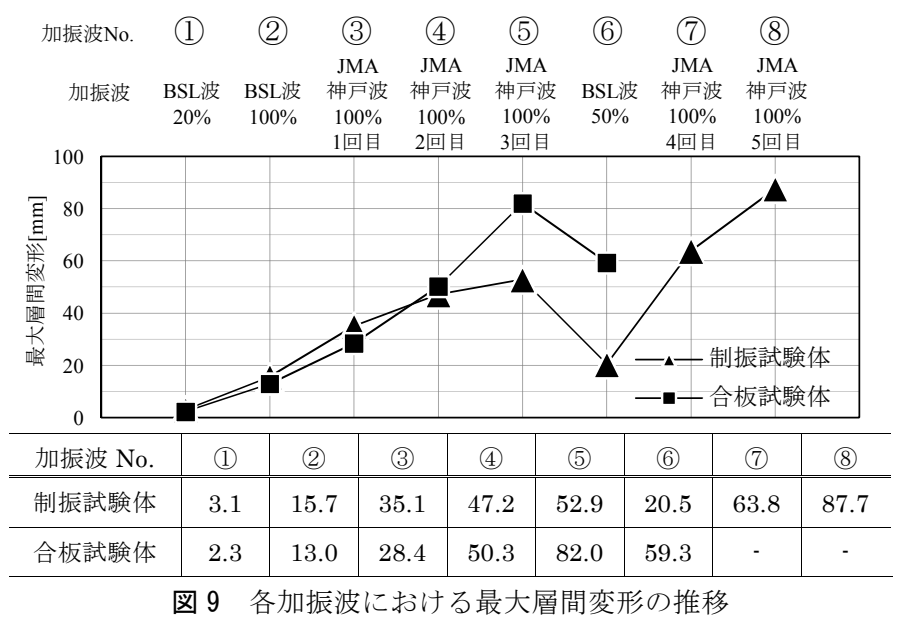

\section{2 最大層間変形の推移と損傷状況}

図 9 に各加振波におけるそれぞれの試験体の最大層間変形の推移 を示す。中地震を想定した BSL 波 $20 \%$ 加振、BSL 波 100\%加振、 JMA 神戸波加振の 1 回目までは制振試験体のほうが合板試験体よ りも変形が大きい。ただし、BSL20\%加振ではその差は $1 \mathrm{~mm}$ 程度 
とわずかである。本研究の主たる対象である JMA 神戸波について みると、1 回目加振の時点では、制振試験体 $35.1 \mathrm{~mm}$ 、合板試験体 $28.4 \mathrm{~mm}$ と合板試験体で $7 \mathrm{~mm}$ ほど変形が小さい。2 回目加振では、 いずれの試験体も変形が大きくなっているが、制振試験体 $47.2 \mathrm{~mm}$ 、 合板試験体 $50.3 \mathrm{~mm}$ となり、この時点で合板試験体の変形が制振試 験体のそれを上回った。同じ加振に対する変形の増加は制振試験体 が 47.2/35.1=134\%、合板試験体が 50.3/28.4=177\%と大きく異なっ ている。3 回目加振で合板試験体に写真 2 に示寸ような合板のはが れなどの損傷が生じ、層間変形は制振試験体 $52.9 \mathrm{~mm}$ 、合板試験体 $82.0 \mathrm{~mm}$ となった。同様に割合を求めると制振試験体の $112 \%$ に対 して合板試験体は $163 \%$ と制振試験体で増加傾向が収まったのに対 し、合板試験体は 1 回目と 2 回目と同様の増加程度となった。この 後、余震を想定した BSL50\%加振を実施した。層間変形は、制振試 験体では $20.5 \mathrm{~mm}$ と BSL $100 \% 1$ 回目より $5 \mathrm{~mm}$ ほど大きな結果と なり、基準法極大地震の応答を上回ることになったが、合板試験体 の $13.0 \mathrm{~mm}$ から $59.3 \mathrm{~mm}$ の変化に比べたら各段に小さいことが確認 できた。合板試験体は合板のはがれなどがみられたため加振をここ で終了した。壁実験での合板のはがれは 1/30rad $(91 \mathrm{~mm})$ 以降で みられることも多く、振動台実験終了時の最大層間変形が $82 \mathrm{~mm}$ で あることを考えると、参考文献 4)でも確認したように繰り返し入力 により損傷も促進されたと考えられる。一方で制振試験体は、その 後も加振を繰り返し、JMA 神戸波 5 回で終了した。3 回目から 4 回 目への増加は $121 \% 、 4$ 回目から 5 回目は $137 \%$ と合板の損傷により 増加傾向にあるが、 5 回目の加振が $87.7 \mathrm{~mm}$ と制振壁の $1 / 3$ 程度の 外力負担によって繰り返し地震動に対する有効性が確認できた。

図 10 に固有振動数の推移を示した。損傷を受けることにより微小 振動による固有振動数が減少するため、固有振動数の推移により損 傷の程度も推定可能と考えられる。BSL100\%加振後までは両試験 体とも損傷がなく、建設時の固有振動数を維持している。JMA 神戸 波 1 回目加振後以降次第に減少し、JMA 神戸波 3 回目加振後は制 振試験体が上回った。具体的な数值についてみると、初期の固有振 動数は制振試験体で $5.8 \mathrm{~Hz}$ 、合板試験体で $6.2 \mathrm{~Hz}$ と合板試験体のほ うが高剛性となっている。余震の BSL50\%加振後では制振試験体 $3.5 \mathrm{~Hz}$ 、合板試験体 $2.4 \mathrm{~Hz}$ と逆転した。

\section{3 層の荷重-変形関係とエネルギ一吸収能力}

図 11 に BSL 波 $20 \%$ 、BSL 波 $100 \%$ 、JMA 神戸波 1 回目、2 回 目、3 回目ならびに、BSL 波 $50 \%$ の加振における各試験体の荷重変 形関係を示す。BSL 波 $20 \%$ 加振より、剛性は制振試験体に比べ合板 試験体のほうが高く、前述したとおり変形も小さい。エネルギー吸 収については後ほど詳述するが、BSL 波 100\%加振においては、制 振試験体の変形が進みループに囲まれる面積も大きく、合板試験体 よりもエネルギーを吸収している。JMA 神戸波 1 回目、2 回目の加 振に関しては荷重変形関係をみる限り、両試験体ほぼ同様の性能と みなせる。3 回目では、制振試験体では紡錘型に似た安定した荷重 変形が得られている。一方で合板試験体は、この加振で損傷を受け たこともあり、壁実験時の $2 、 3$ サイクル目に似たスリップ型の荷重 変形関係となっており、繰り返しによる劣化の影響がうかがえる。 余震を想定した BSL50\%加振では、制振試験体は剛性を維持してい るが、合板試験体においては、一度経験した変形であったので、ス リップ性状を繰り返した。
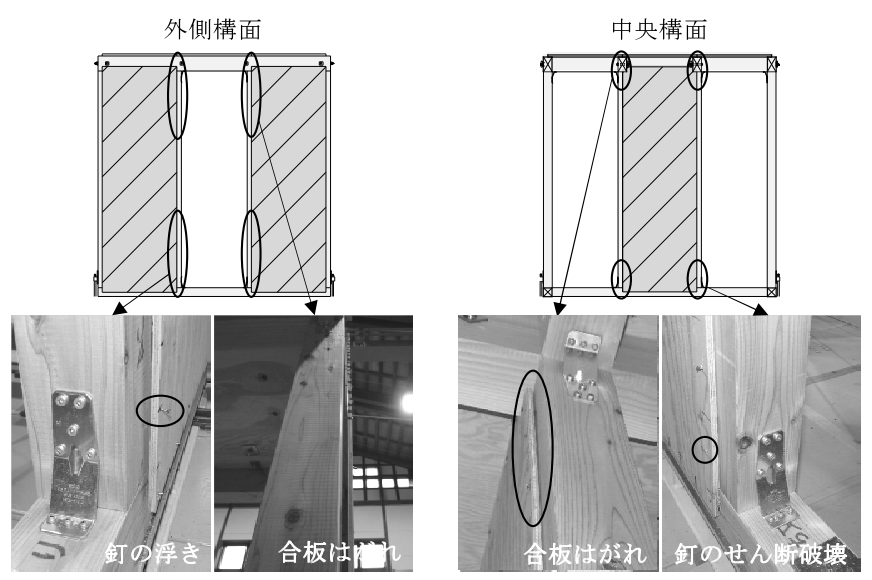

写真 2 JMA 神戸波 3 回目入力後、合板試験体の損傷状況

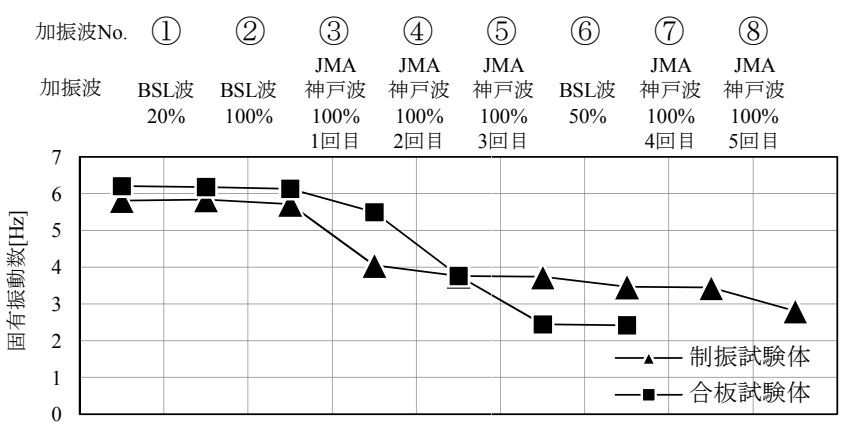

図 10 各加振波における固有振動数の推移
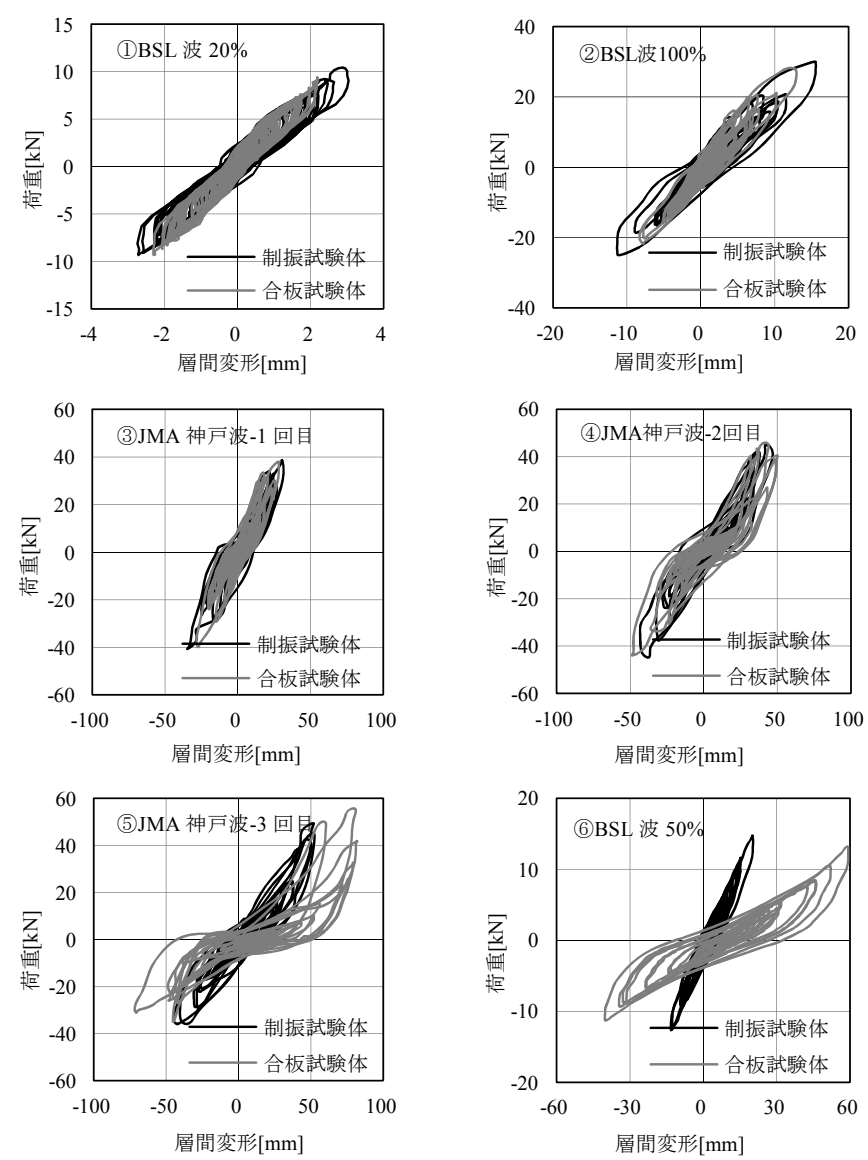

図 11 BSL 波 50\%までにおける各試験体の荷重-変形関係 

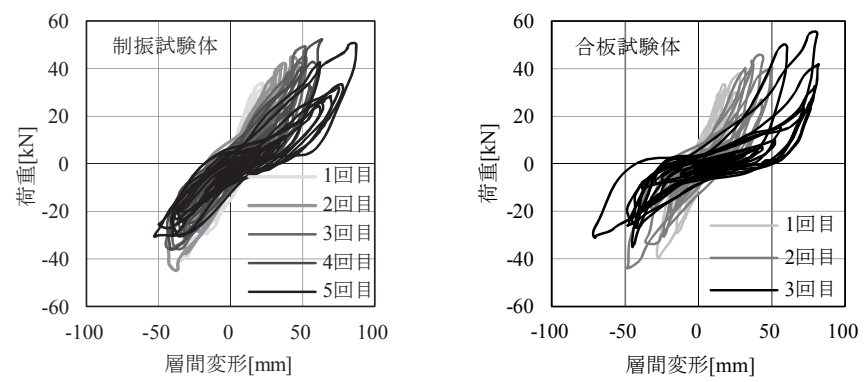

図 $12 \mathrm{JMA}$ 神戸波における各試験体の荷重-変形関係

図 12 にJMA 神戸波加振に対する各試験体の荷重変形関係を示す。 加振を繰り返すにつれて、いずれの試験体においても剛性の低下が 起こっているが、合板試験体に比べ、制振試験体のほうが低下は緩 やかである。図 13 に各試験体の荷重変形関係から得られた履歴面積、 つまりエネルギー吸収を示す。JMA 神戸波 1 回目までは、前述した とおり制振試験体のほうがややエネルギー吸収が大きいが、ほぼ同 じ程度である。その後の JMA 神戸波 2 回目には、合板試験体が制振 試験体を上回った。これは周期が伸びて入力エネルギーが多くなっ たことに起因する。それを確認するため最大応答変位から固有周期 をもとめたものを表 3 にそして図14に速度応答スペクトルを示す。 実験の周期の範囲では周期が伸びると速度応答、つまり入力エネル ギーが多くなることがわかる。図 13 中には制振壁の履歴面積を示す とともに図 15 に制振壁のエネルギー吸収割合を示す。制振壁の負担 する荷重は、歪みゲージで計測した角型鋼管の軸力から縦横比を用 いて算出している。制振壁の設計上の負担割合は約 $1 / 3$ であるが、 JMA 神戸波 1 回目まではその割合に達していない。これは構造用合 板試験体に比べて $1 / 100 \mathrm{rad}$ 程度までの剛性が低いことに起因してい る。JMA 神戸波 2 回目でほぼ設計上の割合に達した。JMA 神戸波 3 回目以降は設計上の負担を上回るとともに余震波や JMA 神戸波 5 回目では制振壁が残りの構造用合板を上回っている。構造用合板が 劣化していく一方で制振試験体のエネルギー吸収能力が維持され、 上昇していることが図 13 からもうかがえる。

図 16 は図 15 と同様の検討を各加振における最大荷重に対して行 ったものである。制振壁の荷重がそれ以外を上回ることはなく、当 然のことであるが、制振試験体は履歴によるエネルギー吸収が優れ ていることを示している。

\section{4 壁実験との比較}

図 17 に壁実験と振動台実験における制振試験体の荷重変形関係 を比較した。BSL 波 $20 \%$ や 100\%における層間変形の比較的小さな 加振では、振動台実験での制振試験体はほぼ弾性挙動であった。JMA 神戸波に対しては、塑性化が生じており、正側と負側で多少差はあ るが、振動台実験における制振試験体は正側、負側いずれも壁実験 の剛性を上回っている。図 18 に層間変形に占めるダンパーの変形割 合を示す。同図中には壁実験の結果を併せて示している。壁実験で は最終的に変形割合が $50 \%$ を超えているのに対し、振動台実験では $30 \%$ 前後の変形割合であった。これは前述したとおり振動台実験が 実施されたのが冬季であり、壁実験が実施された時よりも気温が低 かったことに加え、速度依存性によって、壁実験時に比べ、ゴムが 高い剛性をもったことの結果と考えられる。具体的にそれをみると、 振動台実験時の室内温度は $11 \sim 15^{\circ} \mathrm{C}$ で壁実験のそれは $32^{\circ} \mathrm{C}$ であった。

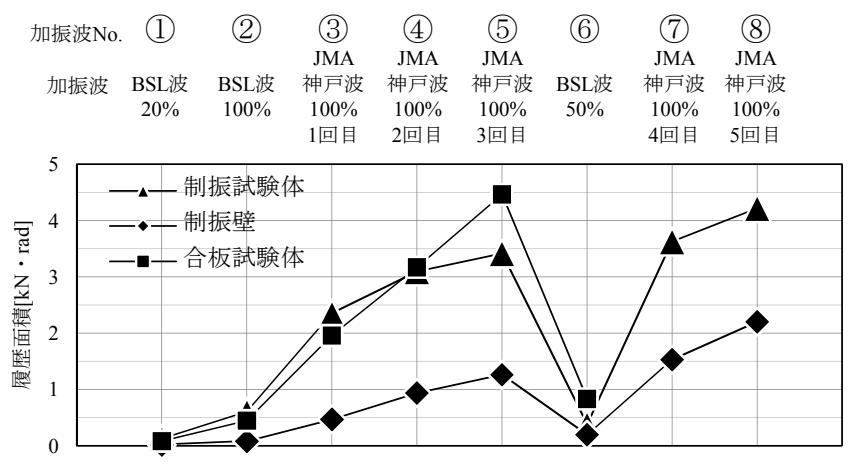

図 13 エネルギー吸収の推移

表 3 固有周期

\begin{tabular}{c|c|c|c|c|c|c|c|c}
\hline 加振波 No. & (1) & $(2)$ & $(3)$ & $(4)$ & $(5)$ & $(6)$ & $(7)$ & ( $)$ \\
\hline 制振試験体 & 0.12 & 0.16 & 0.20 & 0.23 & 0.23 & 0.25 & 0.23 & 0.28 \\
\hline 合板試験体 & 0.11 & 0.15 & 0.18 & 0.24 & 0.30 & 0.46 & - & -
\end{tabular}

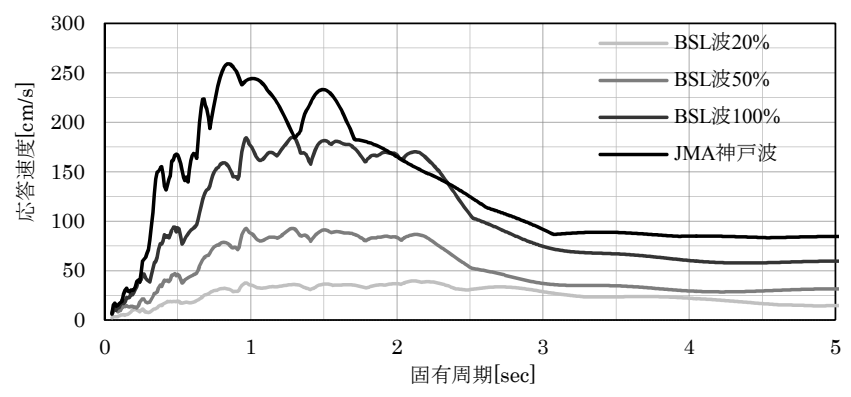

図 14 速度応答スペクトル

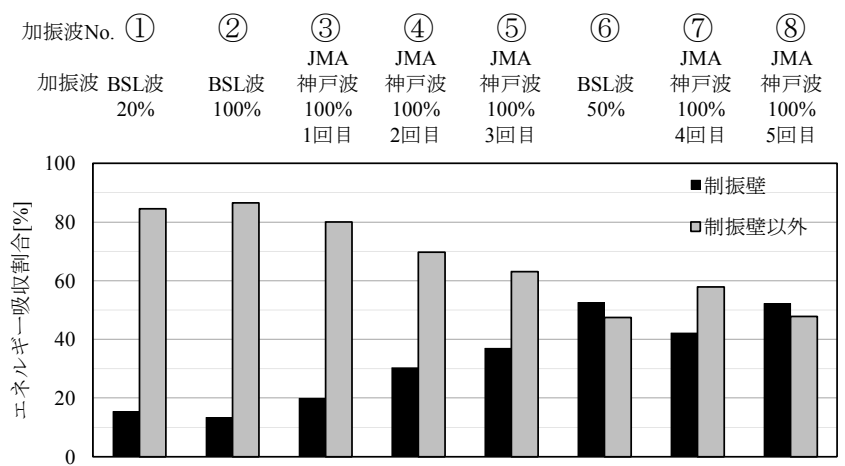

図 15 制振試験体に占める制振壁のエネルギー吸収割合

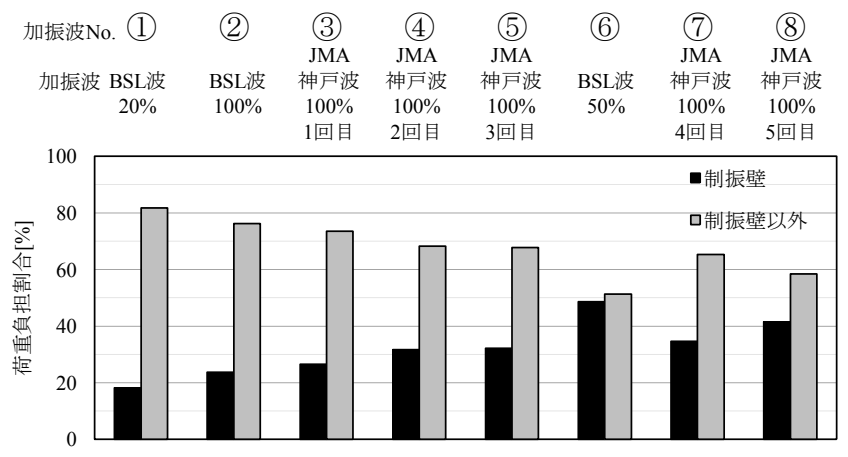

図 16 制振試験体に占める制振壁の荷重負担割合 

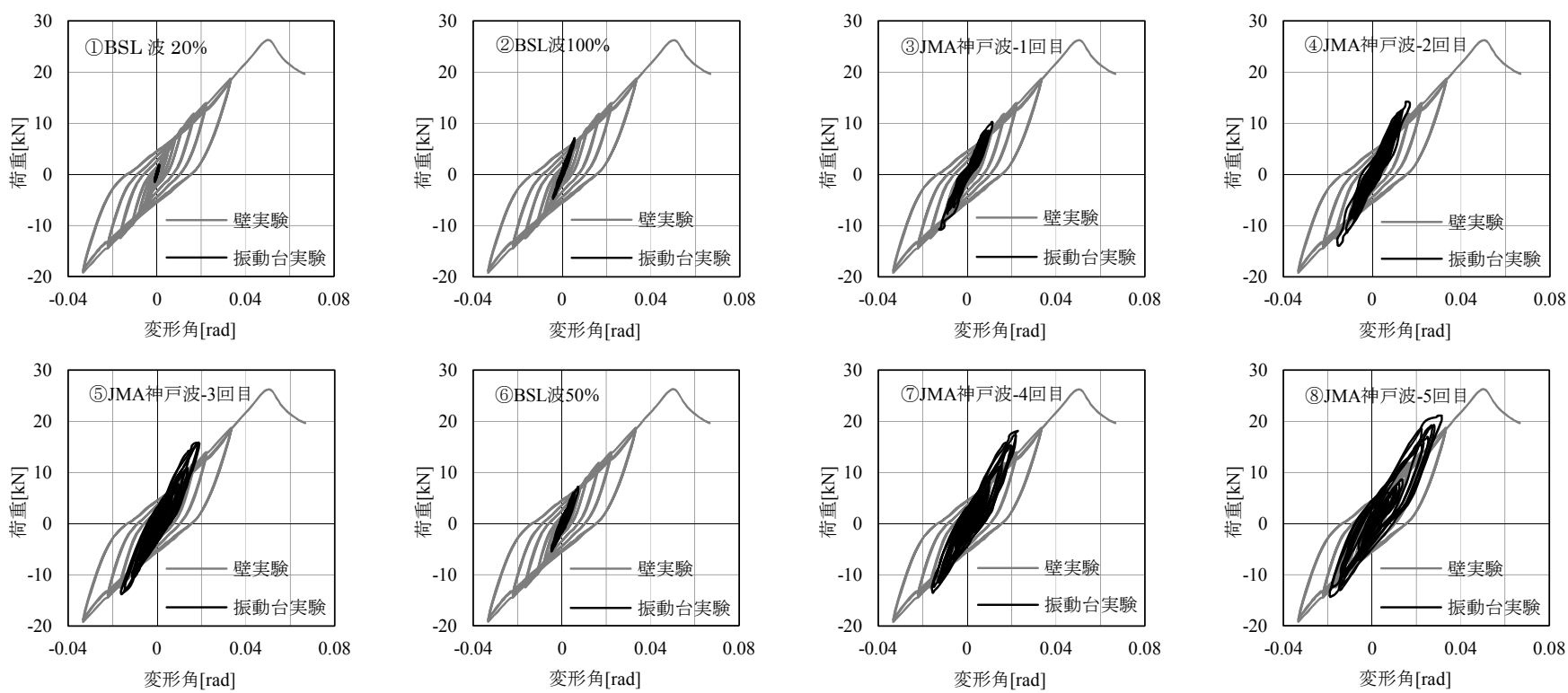

図 17 壁実験と振動台実験における制振試験体の荷重-変形関係

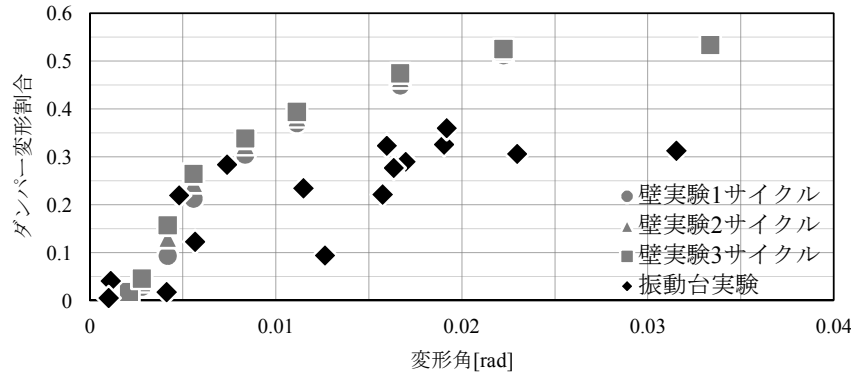

図 18 層間変形に占めるダンパーの変形割合

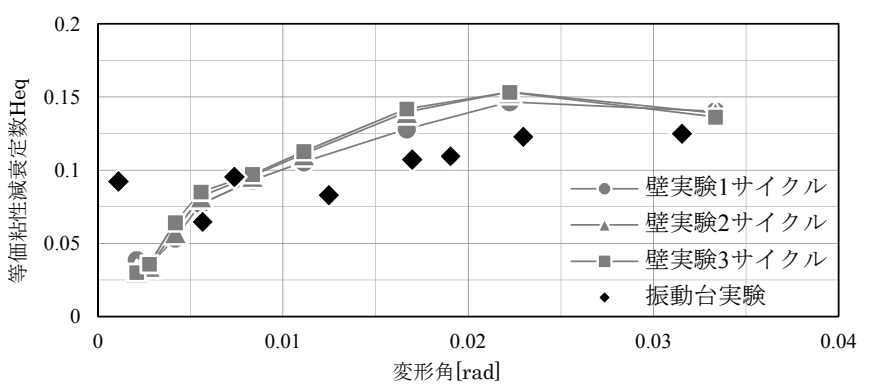

図 19 等価粘性減衰定数

図 1 よりその割合を求めると 1.4 1.5 倍となっている。また、速度 については最大応答時にはゼロであり、変形ゼロ付近での影響が大 きいが、振動台実験では最大速度は $8.3 \mathrm{~cm} / \mathrm{s}$ であった。図 1 では静 的実験の 1.6 倍になっている。このような影響により変形割合が振 動台実験において少なくなったものと考えられる。

図 19 は振動台実験結果の等価粘性減衰定数を示し、壁実験のそれ と比較したものである。前記した依存性の結果として振動台実験の 等価粘性減衰は壁実験より低い。これは周辺部材・接合部の弾性変 形が進んだことによる。高硬度ゴムの剛性が高くなったことにより 壁の剛性が向上したが、減衰は低下した。周辺部材が十分に安全側 に設計されていることによって、この影響による性能低下は防げた ものと考えている。今後、温度が高くなった場合も含め、温度速度 の影響について検討を深める予定である。
5. まとめ

本論文では、構造用合板耐力壁の余震などの繰り返し地震動に対 する応答変形の傾向の一例を示すとともに、制振用高硬度ゴムを用 いた壁の繰り返し地震動に対する有効性を確認した。結果は以下の とおりである。

1）制振壁の壁倍率は 4.3 4.8 程度であり、ほぼ構造用合板壁 $2 \mathrm{P}$ 分 に相当する。耐力を比較すると $1 / 50 \mathrm{rad}$ までは構造用合板壁が大き いが、それ以降は逆転し制振壁のほうが大きい。また、同振幅の荷 重の低下は制振壁がほとんどないのに対し、構造用合板壁は 1 回目 から 2 回目の低下が大きい。履歴曲線で囲まれる面積を比較すると 1/100rad までは構造用合板壁が大きいが、それ以降は制振壁が大き い。

2）以上のような制振壁を、構造用合板耐力壁で構成される平屋建て 模型に組み込み振動台実験を実施した。設計上の負担せん断力は制 振壁が全体の約 $1 / 3$ である。実験においては、この試験体と同等の 性能を持つ構造用合板壁で構成される試験体も用意した。合板試験 体は $1 / 50 \mathrm{rad}$ 程度の変形に至る地震動の繰り返しにより順次応答変 形が増加した。今回用いた JMA 神戸波に対しては、直前の変形を 100 とした場合、2 回目で $177 、 3$ 回目には 163 となった。一方、制 振壁を組み込んだ場合のそれは 134、112であり、増加傾向が抑制さ れた。

3）本振動台実験は冬季に実施した。温度が低下したこと、さらに 壁実験を静加力で実施しており、振動台実験では速度による影響を 受けたため、制振用高硬度ゴムの剛性が高くなった。しかし、周辺 接合部が弾性範囲にあることもあり、壁の剛性が向上し設計上の性 能程度は発揮されているものと考えられるが、今後温度が高くなっ た場合も含め詳細な検討が必要である。

\section{謝辞}

本研究は住友ゴム工業株式会社と信州大学工学部建築学科五十田研 究室（当時）の共同研究の一環として実施した。関係各位にこの場 を借りて感謝する。 


\section{参考文献}

1）（財）日本住宅・木材技術センター：木造軸組工法住宅の許容応力度設 計（2008 年版）、2009.6

2）渡辺哲史, 加藤研一, 福元俊一, 江藤公信 : 東北地方太平洋沖地震とそ の余震に対する日光山輪王寺本堂の振動特性評価、日本建築学会構造系 論文集、No.685、pp.521-528、2013.3

3）梶川久光、三津橋歩、高木良、小川春彦、六車典子、野口弘行 : 木質系 実大耐力壁面の動的挙動に関寸る研究一その 5 繰返しによる影響一、日 本建築学会大会学術講演梗概集、C-1 分冊、pp.457-458、2008.7

4）人見祐策、五十田博、河合直人：大変形と繰り返しによる劣化を考慮し た木造壁の復元力特性モデルー木造建物の地震時挙動に関する研究 そ の 2-、日本建築学会構造系論文集、No.646、pp.2299-2306、2009.12

5）五十田博 : 大変形と繰り返しによる劣化を考慮した木造壁の復元力特性 モデルの精度検証一木造建物の地震時挙動に関する研究 その 3 -、日 本建築学会構造系論文集、No.659、pp.113-120、2011.1

6）下村祥一、大熊武司 : 加力方法の違いが木造軸組工法耐力壁の復元力特 性に及ぼす影響とそのモデル化手法一木造軸組工法耐力壁の耐風性能評 価用復元力特性に関する研究 その 1 一、日本建築学会構造系論文集、 No.607、pp.133-140、2006.9

7）（社）日本免震構造協会：パッシブ制振構造設計・施工マニュアル 第
2 版、p3、2005.9

8）（社）日本建築学会：木質構造基礎理論、p302、2010.12

9）服部学、松本達治、松谷雄一朗、三宅辰哉、松本和行、櫻井重喜、五十 田博、峯村廣紀 : 高硬度ゴムダンパーを用いた住宅用制振試験体の開発 一その 1 構法の概要と壁の繰り返し載荷実験一、日本建築学会大会学 術講演梗概集、C-1 分冊、pp.217-218、2012.9

10）入山朋之、五十田博、松谷雄一朗 : 高減衰ゴムのせん断性能に期待した 面材耐力壁構造の動的挙動と性能評価一高減衰ゴムのせん断性能に期待 した耐力壁を持つ構造に関する研究 その 1 一、日本建築学会構造系論 文集、No.641、pp.1285-1293、2009.7

11）林彦孝、清水秀丸、長岡修、五十田博 : 柱の浮上りを許容した 1 層木質 架構の動的挙動に関する研究、日本建築学会大会学術講演梗概集、C-1 分冊、pp.537-538、2011.7

12）清水秀丸、三宅辰哉、西沼裕介、羽田竜介、五十田博、槌本敬大、河合 直人 : 木造 3 階建て軸組構法住宅の設計法と震動台実験 その 3 建物 重量と入力波、日本建築学会大会学術講演梗概集、C-1 分冊、pp.233-234、 2010.8

（2013年10月10日原稿受理，2014年 1 月10日採用決定） 